\title{
Historical Evolution of English in Bangladesh
}

\author{
Mohammad Nurul Islam \\ Department of English Language, Faculty of Languages and Linguistics, Kuala Lumpur, Malaysia; \\ Department of English Language, Faculty of Languages and Translation, King Khalid University, Abha, Kingdom of \\ Saudi Arabia \\ Azirah Hashim \\ Department of English Language, Faculty of Languages and Linguistics, Kuala Lumpur, Malaysia
}

\begin{abstract}
This paper aims to make a contribution to the study of history and evolution of English in Bangladesh. Bangladesh is a young country, twice-split once from India as a part of Pakistan and then from Pakistan as an independent nation. Therefore, to look at the history, we have to look at the history of English education first in India upto 1947, then in Pakistan (1947-1971) and then only in Bangladesh (since 1971 onwards). The paper begins with how English was brought into Bangladesh; language policy and use in Bangladesh; medium of instruction and also shed lights on the current status of English in Bangladesh.
\end{abstract}

Index Terms - English, history, language contact, education

\section{INTRODUCTION}

Bangladesh, in full The People's Republic of Bangladesh, a republic of Southern Asia, in the northeastern portion of the Indian subcontinent, bordered on the west, north, and east by India, on the southeast by Burma (Myanmar), and on the south by the Bay of Bengal. The area of the country is 147,570 square kilometers (56,977 square miles). The capital and largest city of Bangladesh is Dhaka. Geographically, historically, and culturally, Bangladesh forms the larger and more populous part of Bengal (Statistics Yearbook of Bangladesh, 2011). The population is 167,256,205 (Worldometers, 2019) The national language is Bengali (also known as Bangla), an Indo-European language which is the world's sixth or seventh largest language in terms of speakers. Although Bangladesh is considered to be by and large a monolingual country in which majority of the population is speakers of Bangla language. Whereas a sizeable minority are speakers of more than ten additional languages like Urdu, Monipuri, Chakma, Santali, Garo, Rakhain, Tipra. In a small country like Bangladesh with the presence of ten other languages in addition to Bangla, the linguistic situation and the language distribution presents an interesting scenario. To communicate with the speakers of other languages (intranational and pan-national), we either need to know their language or communicate in a Lingua Franca that is comprehensible to both of us. The facts, therefore, demand that a trilingual situation may be explored in order to determine the use of English as a lingua franca.

\section{How WAS ENGLISH BRought INTO BANGLADESh?}

Education, as is obvious from the extended meaning of the term, is a broad category which includes all disciplines and subjects of study in a formal university set up. It is a blanket term which covers all branches of knowledge, English language being one of them. But we must point out that among other disciplines, English enjoys a special status. English is known as a service language which is used in the teaching and learning of a number of disciplines as a medium. Hence, the overall policy of education in a country provides special space for the teaching and learning of English. We shall discuss in the chapters that follow Bangladesh policy of teaching and learning of English in its historical perspective. A proper historical overview of the status of English in Bangladesh can be made in the following sections:

A. The status and the teaching of English in the pre-independence period, ie, up to 1947(colonial period)

B. The status and the teaching of English in newly created Pakistan (since 1947-1971) or post-colonial period

C. The status and the teaching of English in newly created Bangladesh (since 1971 onwards) or Post-Liberation period (Bangladesh period).

\section{A. The Status and the Teaching of English in the Pre-independence Period, ie, up to 1947 (Colonial Period)}

English Language teaching and learning in India started with the arrival of the British to the sub-continent. When the British arrived, they found three existing education systems in India - first the 'Aryan' system prevalent in the north, second the 'Dravidyan' system in the south and the third was the 'Muslim' system. These systems were mainly based as the role learning of the classical/religious texts (Dakin, 1968, p. 5).

English in India was first motivated by Missionaries who were eager to improve the ethnicity and customs of the natives and to show the flow of knowledge and faith to them. Thereafter, English missionaries began to set up their missions and Christian schools in India (Baldridge, 2002; Kachru, 1983). The 'missionary clause' the East India 
Company of 1698 further encouraged them. But actually, much before that the struggle for language dominance on the Indian land had started in the shape of English-Portuguese competition for lingua-franca (Sinha, 1978, cited in Agnihotri \& Khanna, 1997, p. 20).

The 'Missionaries' efforts in the expansion of English use were strengthened by the political consolidation of the small territories of India by the East India Company. For instance, the Nawab of Bengal was defeated and hence the region fell under the British rule in 1757. Between 1783 and 1790 the moral, social and intellectual situation of the Indian natives were totally subdued (Agnihotri, 1997, p. 21). As a consequence, Charles Grant (residing in Malda) wrote an important treatise 'observations on the state of society among the Asiatic subjects of Great Britain'. In charter act of 1793, Christianity was also motivated for teaching English in India for improving the moral fabric of Indian society. In 1795 the Rajas of Tanjore and Marwar established English medium schools by Reverend Mr. Swartz. Subsequently, Fort William College, Kolkata School Book Society, Kolkata School Society and General Committee of Public Instructions were established.

In 1835, Thomas Macaulay justified the cause of English teaching and learning approved by Governor General Lord William Bentinck on 7 March 1835. Macaulay's Minute of 1835 was intended to reshape policy on the medium and declared English as the language 'best worth knowing' and 'most useful to our native subjects'.

The implementation of Macaulay's Minute was manifested in the establishment of a college at Hooghly in 1836 . In 1840, Macaulay's Minute also manifested a proposal for a college at Dhaka and one at Patna and the transfer and development of Kolkata Hindu College into the Presidency College. Convinced of the superiority of English Language and Literature, the Bengal presidency Report (1844) for the period 1842-43 proposed to promote the Indian languages and cultures.

Sir Charles Wood's Despatch of 1854 modified the filtered education policy of Macaulay and European knowledge among all classes of the people, while the English Language continues to be the most perfect medium for the education. However, English was to remain the medium only of the higher education and the universities that required a knowledge of English. Consequently, new secondary education was applied to anglicize themselves.

Macaulay's policy of selective English for higher education had achieved the greater success and established itself as an academic discipline with the setting up of universities in Mumbai, Kolkata and Madras in 1857 (Dutta, 2001, p. 123). Since then English occupied an important position in the curriculums of schools, colleges and universities of the subcontinent till the end of the British rule.

The Hunter Education Commission of 1882 appointed to inquire the principles of Despatch (1854) and suggested priority to be given to primary education for the masses. Its provision, extension and improvement were to be furnished by the provincial government. The recommendations of Hunter Education Commission further strengthened Lord Curzon's Resolution of 1904 which claimed that the active extension of primary education was one of the most important duties of the state (Dakin, 1968, p. 8).

Though the above policies raised the triple question of (a) the content of education, (b) the spread of education and (c) the medium of education (Dakin, 1968, p. 5), it was for the first time that education in the Indian sub-continent was recognized as the state responsibility.

The scope of English in the colonies such as India added a prestige to the language and its literature and established it as an academic subject. Now a curricula model for English Language and Literature was necessitated. Agnihotri \& Khanna (1997, p. 25) added that the movement for National Education had started much earlier when the partition of Bengal in 1905, and initiated a reaction against English education, its supremacy continued unchecked. The National Council of Education in Bengal was registered in 1906. A variety of changes were introduced by the Morle-Minto reforms (1909). Despite the Montague-Chelmsford report (1917) and the Kolkata University Commission Recommendation (1919), neither the English Language nor the English model of education could reach the Indian masses. The Commission also recommended that the medium of instruction for most subjects upto high school stages was to be the vernacular, but for later stages it should be English.

By the turn of the century, the importance of English was triggered high notwithstanding a gulf kept on widening between the primary education in native language and secondary and higher education in English. English was introduced in the Indian teaching and learning framework in compliance with a request in 1932 by educators like Raja Ram Mohan Roy, Macaulay, Lord Bentinck and Lord Harding. Dakin (1968, p. 8) added that the Sergent Report of 1944 reflects Ghandhi's philosophy. It envisaged universal, compulsory and free education for children between the ages of six to fourteen. The report announced that facility would be provided for adult education for all men and women between the ages of fourteen to forty. The medium of instruction in primary, secondary and adult education would be the vernacular languages.

During the British rule, English was the instrument and language of the colonial power. During this colonial era, English began to take root in India (Kachru,1983) and was used in all formal domains such as administration and education (Misra, 1982). McArthur (2003) has argued that since Bengali is spoken in the Indian state of Bengal and in Bangladesh, and much of the linguistic history of Bengal and Bangladesh has been shared, the English usage of the two territories is similar, and Bangladeshi English usage shares much with Indian English at large (cf. 328).

B. The Status and the Teaching of English in Newly Created Pakistan (since 1947-1971) or Post-colonial Period 
On 14 August 1947, the Indian sub-continent was divided into two countries- India and Pakistan. After getting independence, Pakistan came up with fresh and new ideas, promises and dreams of an ideal state. But like any other newly created states, even Pakistan had to face the challenges to strengthen the existing socio-policio-economic conditions weakened by the long colonization and challenges to build up a bright future. Dakin (1968, p. 4) rightly states (which is true of Pakistan too) that 'unity' and 'progress' are the two main problems that are needed to be solved in relation to a newly independent state. And the only way to both of these is education. In a monolingual society/nation, the problem of medium of instruction does not emerge as a hurdle to educate all, because the local language works as a national language, an official language, as a language of education and other communications. But in a multilingual country, like Pakistan, for instance, the language issue takes a serious shape. In multilingual Pakistan, English functioned as a link language, facilitating communication among linguistically diverse communities (Banu \& Sussex, 2001).

At the time of partition English was the language of Pakistan Government and was taught as a compulsory subject at both primary and secondary level. English also served as the link language between the two parts of Pakistan-'West Pakistan' and 'East Pakistan' (present day Bangladesh) (Dil, 1966, pp. 199-207). The situation, therefore, both in India and Pakistan was the same. While India made Hindi her national language, Pakistan assigned this status to Urdu. While India talked of continuing English as an associate official language for 15 years through Article 343(2) of the Indian constitutional provision, even Pakistan continued it for 20 years through Article 214 of the constitution of Pakistan (Khatun, 1992, p. 85). Pakistan Government came up with the language policies through its constitution, but they could not meet the requirements and aspirations of the common mass and even the demands of science and technology.

Urdu, therefore, was considered to be the national language which even replaced some of the functions of English and other local languages over a period of time. Among the common people English was the symbol of British imperialism. Maulvi Abdul Haq and his vocal group known as 'Baba-e-Urdu', for instance, demanded the replacement of English by Urdu. While others believed that English should continue as an instrumental language because, Urdu was not sufficiently well-developed to assume such an important role for a progressive nation. Even Fazlur Rahman, the first education minister of Pakistan, made a number of policy speeches during 1947 and 1948.

A crisis developed in February 21, 1952, when the language movement started in East Pakistan for the adoption of Bengali along with Urdu, as the national language of Pakistan. The Prime Minister Mohammad Ali Jinnah on May 7 , 1954, specified that English, Urdu and Bengali will be three official languages of Pakistan, until such time that Urdu and Bengali can replace English as the official language.

The constitution of Pakistan 1956 (article 214) clearly specified that English will be continued as the official language for twenty years (Khatun, 1992, p. 85). The first language teaching conference was held at Karachi in March, 1957. The conference was recommended schemes that would improve their teaching and in addition to the development of Bengali and Urdu as state language. We must consider the place of English language as an invaluable medium of communication all over the world. Apart from its present role in Pakistan, English has today attained the status of an international language. In some places like India, Pakistan and many other countries it is functioning as the official language (Dil, 1966, p. 20).

Khatun (1992) stated that on January 3, 1957 the Education Commission was appointed by the Awami league Coalition Government. But the commission's proposals and recommendations remained only a paper work due to the declaration of Martial Law in 1958. Ayub Khan, the then president of Pakistan, also talked of reforming the whole system of education of Pakistan. On June 24, 1960 the Ministry of Education appointed the curriculum committee for secondary education, drawing up curricula in all subjects for class six to twelve. The new secondary syllabus was introduced in 1962 as the first step towards achieving the objectives set out by the curriculum committee, that is, to teach a functional language rather than literature. In 1964, President Muhammad Ayub Khan while addressing in the Urdu College at Karachi that the world is shrinking in books, telegraphs, telephones, airplanes, international trade, political relations and other contacts. Therefore, in such circumstances, the English Language is inevitable for us (Dil, 1966, pp. 203-5).

A number of projects were taken up by the Central Board for the development of Urdu in Lahore and the Board of Dhaka for the development of Bengali. As a consequence, the question of the medium of instruction at primary and secondary levels was resolved more or less in a satisfactory manner among the masses. The University of Karachi took a decision whereby Urdu was being made compulsory as a medium from the year 1965-66, and at the post-graduate level optional from 1965-66, and compulsory from 1967-68. In all other universities much more emphasis was given to Bengali in East Pakistan and Urdu in West Pakistan, but English remained the medium of instruction.

The new teaching and learning policy was the outcome of an intensive review of the entire education system of Pakistan undertaken by a number of study groups following an announcement of President Yahia Khan in 1969, known as New Education Policy. Waseem (1987) argued that English had a renaissance in Pakistan after independence. English generally continued to enjoy a position of vital importance at that time.

Thirteen daily newspapers out of a total 84 were published in English. Besides, a large number of weekly, fortnightly, monthly and quarterly were also published in English. News bulletins and regular programs in English were aired from all stations of Radio and Television of Pakistan. It was estimated that about 2.75 to 3.0 percent of the people could be said to know English at that period in Pakistan. The Commission on National Education had recommended that English 
should be taught as a compulsory language from class vi to xii in schools and at the graduate level of Pakistani educational system (Dil, 1966, p. 212).

In 1950s and 1960s many language teaching conferences, seminars, lectures, symposia, refresher courses were held to suggest appropriate teaching methodology in different parts of Pakistan such as Dhaka, Karachi and Lahore etc. Some of them sponsored by Linguistic Research Group of Pakistan (LRGP), Ford Foundation, Asia Foundation, British Council, Oxford University, The United States Education Foundation in Pakistan (USEFP) and The United States Agency for International Development (USAID) in order to provide an applicable teaching method in relation to English as a second language. But none of them could be able to achieve the goal. Since 1947, the standards of English have shown considerable decline and nationwide concern has been roused to improve the teaching of English at all levels.

\section{Controversy between Bengali and Urdu}

The language controversy was intensified in 1952. On February 21, 1952 a meeting was held at noon on the Dhaka University Campus. The students' leaders were able to excite the students to violate section 144 and stage a demonstration in front of the Provincial Assembly, defying a ban imposed on meetings and processions by the Pakistani Government. In response, the police used tear-gas shells to disperse the crowd, but when students retaliated by throwing stones, they opened-fired, killing several individuals (Imam, 2005). When the news of the killing spread like wildlife throughout the city and other places, the condition became worse. On February 22, 1952 East-Bengal Legislative Assembly recommended to the constituent Assembly of Pakistan that Bengali would be one of the state languages of Pakistan. The resolution by the Provincial Assembly was not enough to pacify the students and politicized sections of the public (Maniruzzaman, 1980, pp. 54-57).

Agitation was still continuing and later, at a conference in Muree in 1955, a formula was agreed upon between the leaders of East and West Pakistan that Bengali and Urdu should be the state languages of Pakistan. Finally, Bengali was accepted as one of the state languages along with Urdu in the constitution of Pakistan in 1956 after a long and bitter battle of about nine years. The martyrs by sacrificing their lives for their mother tongue set an unparalleled example in the history.

Later in 2000, UNESCO marked February 21, 1952 as the International Mother Language Day (Imam, 2005). In retrospect, the Language Movement of 1952 paved the way for the liberation war that culminated in Bangladesh gaining its independence in 1971. From the Bengalis' perspective, the recognition of Bangla as a state language in 1956 was an action that came too late. By then the relationship between the two regions turned bitter to the point that civil war became imminent (Hoque, 2008, p. 5).

\section{The Status and the Teaching of English in Newly Created Bangladesh (since 1971 onwards) or Post-liberation Period (Bangladesh Period)}

East Bengal became a province of Pakistan after the partition of 1947. But feeling the absence of an autonomous status and dissatisfied by the imposing government policies of Pakistan a 'Nationalist Movement' was initiated which saw its culmination in the 'Liberation War' of 1971, and its final victory of December 16, 1971, when East Bengal emerged as a sovereign state, called Bangladesh.

After the liberation of Bangladesh, the new Government initiated the task of reconstructing the 'English language teaching and learning System'. Bangladesh Education Commission was established and the Commission held, "Education policies have close relation with political events and system. Since 1947, Bangladesh witnessed diverse changes in political events. Each change in political life is an instrument for national reconstruction. Therefore, educational policies and their implementation follow closely political ideas of the nation" (Khatun, 1992, p. 9).

Since the introduction of the new curriculum by the Jatiyo Shikkya Upadestha Parishad or National Advisory Council of Education in 1978, English is continued to be taught as a compulsory subject. Though it was the state policy to teach English from class III onwards, in quite a large number of schools, as was in the past, English was started to be taught from kindergarten and nursery onwards. Perhaps the pressure of public opinion was behind the unofficial policy of teaching English from class I of the primary stage of Education in Bangladesh. It is the elite group that largely populates Bangladeshi government agencies in charge of developing language policies in the public school system (Banu \& Sussex, 2001). Bangladesh inherited this format of English language teaching with all its merits and faults even after its emergence as an independent country in 1971, and for a long time could not formulate any new method of Teaching English. There existed no link between secondary and higher secondary education because while the former emphasized language, the later concentrated on literature.

Although English ceased to be the medium of instruction at the secondary level, it remained as the medium of teaching and learning at the higher secondary and university levels. It also remained the only means of communication for official matters. Within a few years, an all-out switch-over was attempted, though not with great success. It took quite a long time to introduce Bangla at all levels of education but higher and technical education still remained dependent on English. Sultana (2012) found that books and journals in central and seminar libraries in various universities in the country were mostly in English. According to his study, in the central library of Dhaka University the total number of books is 7 lakhs of which 55,76,868 were in English, and out of 89,500 journals 78,567 were in English. So, English still enjoys a special status not only among teachers but among students too. Moreover, most administrative jobs whether government or private demand a good command of the English Language. 


\section{LANGUAGe POLICY AND USE IN BANGLADESH}

\section{A. Constitutional Provision}

The Resolution of 1949, the Constitutions of 1956 and 1962 of Pakistan and the Bangladesh Constitution of 1972 are the main sources of constitutional provision of teaching and learning in Bangladesh. Bangladesh made its own constitution within one year of its independence. The objective of National Educational Policy of Bangladesh was derived from the preamble.

"The education of Bangladesh should be inspired with the high ideals of nationalism, socialism, democracy and secularism. The constitution reflected the aspiration of the heroic people who dedicated themselves to and the brave martyrs who sacrificed their lives in the liberation struggle" (Khatun, 1992, pp. 31-32).

The constitution of the People's Republic of Bangladesh 1972 adopted Bengali as the state language in Article (3). Later in 1987, The Bengali Language Introduction Act was passed to provide more muscle power to earlier directives. These steps to broaden the use of Bangla had serious repercussions for English since the expansion of Bangla came at its expense. Bangla took over domains (e.g. education, administration, law, etc.) that previously belonged to English. Commenting on the relationship between English and Bangla, Hamid (2007, p. 3) notes that the two languages are locked in what he describes as "Zero-sum relationship," in which promotion of one leads to usurping the other's space (Choudhury, 2010, p. 6). Although there is no specific mention about the English Language in the constitution, but the emphasis is thus given to building both languages--English is required for development of human resources, but teaching in Bangla is to be continued in earnest since it is linked to national identity (Hoque, 2008, p. 1). Therefore, students are expected to have gained a fairly considerable command of English with which they will be able to effectively communicate facts, ideas and opinions in real-life situations.

When Bangladesh was a part of Pakistan, the constitution of 1956 adopted the principle of language policy (Article 219), and announcement of Bengali and Urdu as the state language was resolved to a certain extent. It also ensured the constitutional provision of keeping English in National life for twenty years. In the spirit of the preamble, Article (17) there are three statements which bear special significance of education.

Article 17: The state shall adopt effective measures for the purpose of:

(a) Establishing a uniform, mass-oriented and universal system of education and extending free and compulsory education to all children to such as may be determined by law;

(b) Relating education to the needs of society and producing properly trained and motivated citizens to serve those needs;

(C) Removing illiteracy within such time as may be determined by law.

(S. Malak, Begum, Habib, Shaila, \& Moninoor, 2013).

These constitutional provisions serve as a guide for educational planning and development. Bangladesh took a democratic stand in detailing the need for an education system, which reaches every child. This deal continues to provide a frame work for mass education and these provisions were quoted in the five years plan of Bangladesh (M. S. Malak, 2013).

\section{B. Government Policies}

In the post-independence Bangladesh, several educational bodies were formed by the Government in different phases. The recommendations of these bodies contributed to the development of contemporary teaching and learning policy of Bangladesh.

Bangladesh Education Commission suggested measures to the Government for enabling it to remove weakness and failures of the existing education system and to give guide line for national reconstruction in the spirit of the new philosophy of the state.

In Bangladesh, a number of foreign languages like Arabic, Urdu, Persian, French, German and Japanese etc. are taught in the universities. English however is taught as a mandatory subject at primary, secondary, higher secondary and college levels (Khatun, 1992, pp. 65-66).

Describing the English language policy in public and private Bangla-medium schools, Hussain and Tollefson (2007) state, "sometimes English has been encouraged, sometimes it has been limited, and sometimes it has been forbidden," with the result that currently only about 3\% of the population uses English as a second language" (cf. 241).

Dove's (1983) examination of the educational policies in Bangladesh from 1971 to 1981, demonstrates that there was, in fact, a gap between policy goals an implementation. She maintains that the explanation for this gap lies in the sociopolitical context in which educational policies were generated and implemented. She noted that this policy was not earnestly followed since elite wanted English education for their children. Therefore, she sees a gap between policy and practice in spite of some progress that was made during this period:

Throughout all these shifting views on language policy and education, even though the national policies generally favored Bangla, the elite continued to invest in English- medium education (Banu \& Sussex, 2001; Dove,1983; Imam, 2005). As a result, Private University Act in 1992 was passed, which helped establish English-medium private universities in the country (Hamid, 2007, p. 4; cited in Hoque, 2008, pp.10, 12)

The Indian sub-continent was a British colony for two hundred years. It was the British colonial rulers, that firmly established English as a compulsory curriculum subject by introducing English teaching and learning in this sub- 
continent in the first half of the 19th century. Since then English has been an important component of our national curriculum (Hoque, 1997, p. 130).

\section{Present Day English Language Teaching Scenario in Bangladesh}

By now it is clear that Bangladesh is a new nation and carried the socio-cultural heritage of Pakistan and India. Both have influence on the present education system of Bangladesh. The main elements of the previous system were laid during the British rule of India and consolidated during Pakistan times. Between 1947 and 1971, there was no radical thinking or major reforms in the field of education to make it more relevant to the present day problems.

During the last few decades, English Language Teaching has undergone a great change all over the world even in Bangladesh where English was once the second language and acted as the lingua franca to interact with West Pakistan. Bangladesh came into existence as a sovereign state with some radical socio-political and economic philosophy. Naturally, it could not be satisfied with a system of education which was designed by the Pakistani Government. So after liberation, the new country had to reconstruct its society and make a rapid progress according to its new sociopolitical and economic philosophy. In this great nation building task, the founders of Bangladesh thought education would play a vital role.

The traditional English teachers strongly opposed when new theories of ELT (CLT) crept into Bangladesh. The main reason is that they were not ready for something new. Another reason is that their forefathers had learnt English from the British rule in the same manner (i.e. through Grammar- Translation method) and they were quite successful in their lives. Therefore, teachers do not want to practice anything new. They were also unable to realize any change in the status of English. The different methods and techniques of teaching were implemented through teachers' training. So far teachers of English considered literature and grammar as the only means of teaching English Language. But these groups knew a little or nothing about the teaching of the four skills in the beginning which are crucially important for the teaching of any language (i.e. teaching of listening, speaking, reading and writing).

English is a compulsory subject which occupies an important place in National Curriculum. It needs to be taught with great care and attention. Teaching a language in general and teaching a foreign language in particular is a complex enterprise which involves the risk of wasting efforts on the part of an unskilled teacher. Most of the parents are aware of the need for English. They encourage their children to learn and to use English inside and outside. They feel their children need to learn English because globally it is the common medium of communication.

It is generally believed that language means the teaching English literature textbooks. However, they forget that the main purpose of teaching English is not to equip our students to appreciate literature, but to prepare them to be able to interact in actual social situation (Hoque, 1997, pp. 135-38).

To determine current status of English Language Teaching (ELT) in Bangladesh the prevalent trends of ELT need to be examined. In most educational institutes at the university level, English is being taught as a literature subject but hardly any focus on language teaching. It is only recently that the authorities have decided to make English a compulsory subject to be studied by the students of all departments of the Faculty of Arts at Dhaka University.

\section{Medium of Instruction}

The main purpose of teaching English is to acquire language skills and not to learn any particular subject. It is also to enable students to interact in it in real-life situations. The themes and topics introduced in the syllabus are meant to be used as vehicles for practicing all four skills effectively. Therefore, the situation demands that English should be taught as a functional or operational language.

According to a popular belief, the main aim of teaching English in Bangladesh is to enable students to use it as a 'library language' in the higher education both at national and international levels.

But such naming gives the impression of a confined role of the language, while it remains a fact that the use of English in Bangladesh is as expanded and dynamic as in any modern country of the world, ranging from interpersonal use to international communication.

The Report of the commission on National Education (1960) Chapter III (P-III, P-147), put a greater emphasis on English language education in comparison to Bengali, Science and Mathematics. The commission also suggested that English should be taught as a functional language at all levels. The teachers must be properly trained before they enter services. All sorts of effort should be made by the authorities, the schools and the communities to provide facilities such as classroom, laboratories, workshops, libraries, garden-plots, play-ground and equipment in order to cover achievement of secondary education. Explaining the importance of English in international communication, the President of Bangladesh emphases that with a view to promoting employment abroad and encouraging transfer of technology, emphasis will be laid on teaching English language beside the mother tongue (The Daily Observer, 2002; cited in Imam, 2005, p. 477).

\section{Primary level}

Teaching of any foreign language is not justifiable at primary stage both on pedagogical and psychological grounds. Meanwhile, the Government of Bangladesh undertook a massive project to reconstruct and develop the education system (Dove, 1983). The educational policy of the time was committed to providing more access to basic education for all (Hoque, 2008, p. 6). As there was public demand for English, it was introduced in the last two classes of the primary school. This state of English remained the same in post-independent Bangladesh, although Bangladesh Education 
Commission did not recommend any foreign language at primary level. At present unofficially English is taught from class one in many of the primary schools and even in nursery and kindergarten school (Khatun,1992, p. 99). Students at the end of primary level education are expected to have acquired an elementary command on the four language skills of English. The general skills of English which they acquire are likely to enable them to carry out simple language activities such as spoken, greetings, farewells, reading signboards, addresses and writing ordinal numbers such as first, second, third etc. The main purpose of teaching English at this stage is to prepare the students for more serious and intensive study of the language for secondary level.

2. Secondary level

Secondary education has been regarded as the most critical stage of any national system of education (Salam, 1956, p. 41). By the end of the secondary level education, students undergo studying of English as a compulsory subject for about ten years. During this long period, students study it seriously and in great detail. By class X (ten), students study about 2000 vocabulary and 20 basic structural patterns as well. Students also acquire about four language skills with greater emphasis on reading and writing skills because students' performance in the examination depend mainly on reading comprehension and writing ability (Hoque, 1997, p. 148). At this stage, students are also required to use reference books like dictionaries and to translate passages from Bengali into English and vice-versa which enable them to use English more effectively. A point to note here is that currently there are 317 Bangla-medium public secondary schools, which employ 7,434 teachers, and 13,224 private secondary schools, which employ 1,78,269 teachers, in Bangladesh (Ministry of Education Statistics, 2005), but all follow the NCTB prescribed curricula. After grade 10, students, both from public and non-government schools, are required to sit for a state mandated examination--the secondary School Certificate (SSC). The examination follows a common national content, but is administered regionally (Imam, 2005; as cited in Hoque, 2008, p. 13).

3. Higher Secondary level

After passing the secondary examination, students enroll themselves for higher secondary studies; some of them take up vocational education, while others for some socio-economic reasons, put an end to their academic life. In fact, the teaching of English at this level may be looked upon as a continuation of the secondary level study. The main objective of teaching English at this level is to extend and strengthen the command of language skills which students have already acquired at the secondary level through revision and practice activities.

During these two years, students are expected to acquire an additional vocabulary of 6 to 8 hundred head-words. Further, they also practice additional structural patterns mainly with conditional clauses (such as unless...... even, if......, since....., etc.). At this stage, they also study short stories and poems mainly for understanding, enjoyment and have to answer comprehension questions in the examination (Hoque, 1997, p. 151). Besides, the four basic language skills, students have to acquire a fairly considerable command of the reference and translation skills with the help of dictionaries and reference books, which are related to other subjects of study.

Generally better resourced than the Bangla-medium schools, Imam (2005) observes that English-medium schools (which, as previously mentioned, are private) follow a globalized curriculum, developed in the United Kingdom (UK). In these schools, all subjects are taught in English, except Religious studies and Bangla. Bangla is an optional subject, and those who take it seldom reach competency beyond grade 5 standard in writing (Imam, 2005). In accordance with the curriculum, the textbooks (as well as the other teaching materials) and the assessment are also developed in the UK. The assessment referred to as General Certificate of Education has two levels: Ordinary Level (O levels in short), taken at the tenth year of schooling, and the Advanced Level (commonly referred to as A Levels), taken at the twelfth year, are prepared by the London Board of Examinations and facilitated by the British Council (Imam, 2005). After passing A Levels, the students from these schools take admission either in private English-medium universities or travel abroad for further studies. In fact, English-medium schools flourished because the wealthy or the elite in the country favored English education (Imam, 2005; cited in Hoque, 2008, pp. 11-13).

Higher Secondary education is seen not as a conclusion of secondary education, but rather as preparation for fouryear college or university. Admission in college, therefore, depends greatly on students' performance in the SSC and HSC examination.

4. Tertiary Level

Students at the tertiary level seek a wide range of higher study options. Some of them enroll in medical colleges, some of them in engineering colleges and some of them enroll in agriculture colleges for higher study, while others enroll in colleges and universities to study degree pass or honors' courses in different faculties and subjects.

Under the National University, degree pass and honors' students study one paper of compulsory English consisting of 100 marks. The main objectives of teaching English are to reinforce the skills which students have already acquired through remedial teaching. Students also need to be taught elements of English for specific purposes (ESP) such as English for medicine, engineering and agriculture, etc. with special emphasis on reading and writing skills. The listening and speaking skills also necessitate for both effective learning and use in real-life situations when needed (Hoque, 1997, pp. 153-54). The private University Act in 1992 was passed, which helped establish English-medium private universities in the country (Hamid, 2007, p. 4). The Act allowed the setting up of some 80 universities (UGC, 2014). These universities place special emphasis on English because English is in much demand. 
For higher education English was made an optional subject (hitherto it was a compulsory subject) in 1980 (Rahman, 1999). Nevertheless, the transition from English to Bangla was more gradual at the tertiary level. This gradual shift was largely due to the fact that translation of books and other materials into Bangla took considerable time; hence, English continued to be used as a medium of instruction alongside Bangla at this level (Rahman, 1999). English is the most widely spoken language after Bengali in Bangladesh (Bangladesh, 2012).

\section{CONCLUSION}

Nowadays English is started to be taught from first level education. All the students from class 1 to 14 have to study the same English courses though all of them do not need the same English courses for their study or real life situations. Hence, what is needed in the national level policy for ELT is to identify the practical necessities for English in the society. The trained teachers, communicative learning materials, financial, infrastructure and management facilities can only meet the above conditions.

\section{REFERENCES}

[1] Agnihotri, R. K. \& A.L. Khanna (eds). (1995). English Language Teaching in India. Sage Publication, New Delhi.

[2] Agnihotri, R. K., Khanna, A. L., \& Ahluwalia, N. (1997). Problematizing English in India. New Delhi, India: Sage Publications.

[3] Alam, S. (2002). On the proposed education policy: some proposals regarding languages (in Bangla). In H.A. Shahed(Ed.), Bangladesher shikkha babostha (pp. 515-525). Dhaka: Suchipatra.

[4] Alam. F., \& Zaman, N. (2001). Preface. In F. Alam, N. Zaman, \& T. Ahmed (Eds.), Revisioning English in Bangladesh (pp.1525). Dhaka: University Press Limited.

[5] Alam.F., Zaman,N. \& T.Ahmed (Eds.) (2001). Revisioning English in Bangladesh. The University Press Limited, Dhaka.

[6] Annamalai, E. (2001). The colonial language in multilingualism and the process of modernization. In E. Annamalai (Ed.), Managing multilingualism in India: Political and linguistic manifestations (pp. 89-124). New Delhi: Sage.

[7] Annamalai, E. (2004). Medium of power: The question of English in education in India. In J. Tollefson\& A, B.M. Tsui (Eds.), Medium of instruction policies - Which agenda? Whose agenda? (pp. 177-194). Mahwah, NJ: Lawrence Erlbaum.

[8] Banu, R., \& Sussex, R. (2001). Code-switching in Bangladesh. English Today, 17(02), 51-61.

[9] Banu, R., \& Sussex, R. (2001). English in Bangladesh after independence: Dynamics of policy and practice. Oxford University Press.Oxford.

[10] Banu, Rahela and Roland Sussex. (1999). 'English in Bangladesh after independence: dynamics of policy and practice.' Paper presented at the Conference on Colonial Englishes, Australian National University, October 1999. To be published in the conference proceedings by the Oxford University Press.

[11] Crystal, D. (2003). English as a Global Language. 2nd edition. Cambridge: University Press.

[12] Dakin, J. (1968). 'Language and education in India', in J. Dakin, B. Tiffien \& H.G. Widdowson (eds.), The Language in Education: The Problem in Common Wealth Africa and the Indo-Pakistan Subcontinent, Oxford University Press, London, 161.

[13] Dill.S. (1966). The position and Teaching of English in Pakistan. Pakistani Linguistics Series (Sahidullah Presentation Volume) Linguistics Research Group of Pakistan, Lahore.

[14] Directorate of Secondary and Higher Education(DSHE). (2004). Evaluation report of ELTIP: phase -2. (Memo no. 39722/10GA). Dhaka: Directorate of Secondary and Higher Education.

[15] Dove, L. A. (1983). Education policy in Bangladesh1978-81: Promise and performance in political perspective. Comparative Education, 19(1), 73-88.

[16] Dutta, S. K. (2001). English Language and literature in Bangladesh: Towards a methodology. In Alam.F., Zaman, N. \&T. Ahmed (Eds.) 2001. Revisioning English in Bangladesh (pp. 123-140). Dhaka: University Press.

[17] Education in Bangladesh. (1972). Ministry of Education, Dhaka.

[18] Government of Bangladesh. (1994). The constitution of the People's Republic of Bangladesh. Amendment upto (1994). New Al-Jalaj Book Agency, Dhaka.

[19] Hoque, M. E. (2008). M. Phil. in English Language (Applied Linguistics and ELT) (Doctoral dissertation, Jahangirnagar University).

[20] Hoque, M. S. (1997). English Language Teaching and Learning in Bangladesh. Bangladesh Open University.

[21] Hoque, M.E. (2008). English Language Teaching and Learning at the Alim Level in the Madrashas in Bangladesh: Problems and Possible Solutions. Unpublished M.Phil. Thesis. Dhaka: Jahagirnagar University.

[22] Hossain, T., \& Tollefson, J.W. (2007). Language policy in education in Bangladesh in Tollefson \& A. B. M. Tsui (Eds.), Language policy, culture and identity in Asian contexts (pp. 241-257). Mahwah, NJ: Lawrence Erlbaum Associates.

[23] "http://www.worldometers.info/world-population/bangladesh-population/ Retrieved on Februarylst, 2002".

[24] Kachru, Braj. B. (1978). Code-mixing as communicative strategy: In International Dimension of English education (ed.) James E. Alatis. George Town University Press.

[25] Kachru, Braj.B. (1983). The Indianization of English: The English Language in India. Delhi. Oxford University Press.

[26] Kachru, Braj.B. (1985). 'Standards, Codification and Socio-linguistic Realism; the English Language in Outer Circle; in Quirk and Widdowson (eds.) English in the World, pp.11-30.

[27] Kachru, Braj.B. (1992). 'World Englishes and Applied Linguistics' in Koul, Omkar N.(ed.) Creative New Delhi.

[28] Khatun, Sharifa. (1992). Development of Primary Education policy in Bangladesh. University of Dhaka, Dhaka.

[29] Laird, M. A. (1972). Missionaries and education in Bengal, 1793-1837. Oxford University Press. Oxford.

[30] Mahathir, M. (1999). A new deal for Asia. Petaling Jaya, Selangor: Pelanduk Publications.

[31] Malak, M. S. (2013). Inclusive Education in Bangladesh: Are Pre-service Teachers Ready to Accept Students with Special 
Educational Needs in Regular Classes? Disability, CBR \& Inclusive Development, 24(1). https://doi.org/10.5463/dcid.v24i1.191.

[32] Malak, S., Begum, H. A., Habib, A., Shaila, M., \& Moninoor, M. (2013). Inclusive Education in Bangladesh: Policy and Practice. Joint AARE Conference, Adelaide, 1-15.

[33] Ministry of Education (1997). Kurd-at-e-Khuda commission report [National Education Commission Report]. Dhaka: Government of the People's Republic of Bangladesh.

[34] Ministry of Education (1997). National education policy 1998.Dhaka: Ministry of Education.

[35] Nical, I., Smolicz, J. J., \& Secombe, M. J. (2004). Rural students and the Philippine bilingual education program on the island of Leyte. Medium of instruction policies-which agenda? Whose agenda, 153-176.

[36] Pakir, A. (2004), Medium of instruction policy in Singapore. In J. Tollefson \& A.B.M. Tsui (Eds.), Medium of instruction policies - Which agenda? Whose agenda? (pp. 177-194). Mahwah, NJ: Lawrence Erlbaum.

[37] Rahman, A. (2007), The history and policy of English education in Bangladesh. In Y.H. Choi and B. Spolsky, (Eds.), English education in Asia: History and policies (pp. 67-93). Seoul: Asia TEFL.

[38] Rahman, A. M. M. H. (1999). English language teaching in Bangladesh: Diadactics on the pragmatics of a language teaching policy. In T. Hunter (ed.), Collected papers of the international conference on national and regional issues in English language teaching: International perspectives (pp. 5-32). Dhaka: British council.

[39] Rahman, M. H. (2004). An evaluation of the teaching of reading skills of English in Bangladesh. Master in English. Retrieved July 10, 2018 from http://www.asian-efl-journal.com/Thesis/Thesis-Rahman.pdf/.

[40] Rehman, Tariq. (1999). Language Education and Culture. Oxford: University Press

[41] Rumnaz Imam, S. (2005). English as a global language and the question of nation - building education in Bangladesh. Comparative Education, 41(4), 471-486.

[42] Salam, A.K.M. (1956). Improvement in Secondary Education. Published by Mrs. Akikan Nessa Khatoon. University Press Ltd. Dhaka.

[43] Sattar, E. (1982). Universal primary education in Bangladesh. University Press. Dhaka.

[44] Selim, A., \& Mahboob, T.S. (2001). ELT and English Language Teachers of Bangladesh: A profile. Revisioning English in Bangladesh. Alam, F., Zaman, N., \& Ahmed, T. (Eds.). University Press. Dhaka.

[45] Sinha, B. S. (2001). English phobia in our schools and colleges. A.Alam, N.Zaman,. \&T.Ahmed (Eds.). Revisioning English in Bangladesh (pp. 169-175). Dhaka: The University Press.

[46] Sridhar, S.N. (2008). Language contact and convergence in South Asia. In Kachru, B.B., Kachru,Y. \& Sridhar, S.N.(Eds.).2008. Language in South Asia. (pp.237). Cambridge: University Press.

[47] Statistics, B. B. O. (2011). Statistical Yearbook of Bangladesh. Statistics Division, Ministry of Planning, Dhaka, Government of the People's Republic of Bangladesh.

[48] Sultana, S. (2012). Problematising the popular discourses about language and identity of young adults in bangladesh. $3 L$ : Language, Linguistics, Literature, 18(4), 49-63.

[49] The daily Observer (2002, February1). Opposition indispensable part of Govt. Retrieved February 1, 2002, from http:/www.Bangladeshobserveronline.com/new/2005/09/01/index.html.

[50] University Grants Commission. (2016). Annual Report 2014 (part-1-2). Dhaka: UGC. August 4, 2018, from http://www.ugc.gov.bd/en/home/downloadfile/24.

Mohammad Nurul Islam is a research scholar in the field of Varieties of English, Faculty of Languages and Linguistics, University of Malaya, Malaysia. Moreover, he is an Assistant Professor in ELT, currently working in the Department of English, Faculty of Languages and Translation at King Khalid University, Abha, Kingdom of Saudi Arabia. He has been teaching ELT and ESP at the tertiary level more than a decade. His research interests include: ELT, ESP, and language testing. He has published many articles in professional refereed journals.

Azirah Hashim is a Professor at the Department of English Language, Faculty of Languages and Linguistics, University of Malaya, Malaysia. Moreover, she is an Executive Director, Asia-Europe Institute (AEI) and Director, Centre for ASEAN Regionalism (CARUM), University of Malaya 50603, Kuala Lumpur, Malaysia. She is the Vice President of International Association of Applied Linguistics (AILA). 